\title{
Risk of mini-mental state examination (MMSE) decline in the elderly with type 2 diabetes: a Chinese community-based cohort study
}

\author{
Lei Zhao', Chao Han², Zheng Zheng ${ }^{2}$, Shuang Ling Xiu ${ }^{1}$ and Piu Chan ${ }^{3,4,5,6,7,88^{*}}$
}

\begin{abstract}
Background: We aimed to investigate the correlation of factors involved in the change of Mini-Mental State Examination (MMSE) and type 2 diabetes in the elderly.

Methods: This study was a secondary analysis of a prospective cohort study. Type 2 diabetes patients aged $>55$ years were recruited and assigned into three groups based on their glycated hemoglobin (HbA1c) levels: HbA1c < $7,7 \% \leq \mathrm{HbA} 1 \mathrm{c}<8 \%$ and $\mathrm{HbA} 1 \mathrm{c} \geq 8 \%$. MMSE decline was considered the endpoint. Factors related to MMSE decline were identified by univariate and multivariate regression analyses.

Results: Altogether, 1519 subjects were included, 883 in the Low group, 333 in the Median group, and 303 in the High group. Age $\geq 75$ years, education below elementary school level, not participating in seminars or consultation on healthcare, physical activity less than $30 \mathrm{~min} /$ day, cerebrovascular disease history, MMSE score at baseline, and $\mathrm{HBA} 1 \mathrm{C} \geq 8 \%$ were associated with cognitive decline by univariate and multivariate analysis. When the other factors were adjusted for, $\mathrm{HBA} 1 \mathrm{C} \geq 8 \%$ was independently associated with the severity of cognitive decline $(\beta=0.58,95 \% \mathrm{Cl}$ : $0.06-1.11, P=0.029$ ) and the occurrence of cognitive decline (odds ratio $(\mathrm{OR})=1.55,95 \% \mathrm{Cl}: 1.13-2.12, P=0.007$ ).

Conclusions: In elderly patients with type 2 diabetes, $\mathrm{HbA1c} \geq 8 \%$ is an independent factor for cognitive decline and is also associated with the severity of the cognitive decline.
\end{abstract}

Keywords: Diabetes mellitus, Type 2, Cognitive dysfunction, Aged, Glycated hemoglobin a, Risk factors

\section{Background}

The number of people with diabetes mellitus is increasing rapidly and has more than doubled globally in thirty years, making it a major public health challenge for all nations [1]. Around $90 \%$ of cases of diabetes are type 2 diabetes mellitus (T2DM), and this is particularly important in China, which is an epicenter for the global

\footnotetext{
* Correspondence: pbchan@hotmail.com

${ }^{3}$ Department of Neurobiology, Geriatrics, and Neurology, Xuanwu Hospital, No. 45 Changchun St., Xicheng District, Beijing, China

${ }^{4}$ Department of Neurology, Beijing Institute of Geriatrics, Xuanwu Hospital of Capital Medical University, Beijing 100053, China

Full list of author information is available at the end of the article
}

T2DM epidemic [2]. T2DM is associated with a wide range of complications, including cardiac diseases, diabetic foot, and diabetic nephropathy [3]. However, the adverse impact of T2DM is not limited to these common diseases, and it is also associated with exacerbation of age-related decline in physical and cognitive function [4].

Individuals with T2DM score less well on cognitive function tests such as the Mini-Mental State Examination (MMSE) than those without diabetes [5], and a clear relationship between diabetes in midlife and greater cognitive decline has been demonstrated $[6,7]$.

(c) The Author(s). 2020 Open Access This article is licensed under a Creative Commons Attribution 4.0 International License, which permits use, sharing, adaptation, distribution and reproduction in any medium or format, as long as you give appropriate credit to the original author(s) and the source, provide a link to the Creative Commons licence, and indicate if changes were made. The images or other third party material in this article are included in the article's Creative Commons licence, unless indicated otherwise in a credit line to the material. If material is not included in the article's Creative Commons licence and your intended use is not permitted by statutory regulation or exceeds the permitted use, you will need to obtain permission directly from the copyright holder. To view a copy of this licence, visit http://creativecommons.org/licenses/by/4.0/ The Creative Commons Public Domain Dedication waiver (http://creativecommons.org/publicdomain/zero/1.0/) applies to the data made available in this article, unless otherwise stated in a credit line to the data. 
Although the association in elderly patients is less clear because of the small numbers investigated [8].

Hemoglobin A1C (HbA1c) or glycated hemoglobin represents a measure of the blood glucose levels over the previous three months. HbA1c can evaluate glucose control in individuals with diagnosed diabetes and can also be used in diagnosing diabetes and people at risk of developing diabetes [9]. HbA1c is associated with cognitive decline [10]. Most, but not all [11], cross-sectional studies associate higher levels of HbA1c with worse cognitive function in individuals with T2DM $[12,13]$. This suggests that poor glycemic control is an important factor related to cognitive decline. But the studies using high HbA1c levels to measure this have shown some conflicting results $[4,14-17]$. Therefore, at the moment, the association between $\mathrm{HbA} 1 \mathrm{c}$ and cognitive decline in patients with T2DM remains unclear. A study in elderly patients found diabetes, poor glycemic control, and longer diabetes duration were all associated with incident cognitive impairment. However, in persons with wellcontrolled diabetes, as assessed by HbA1c, there was not a significantly higher risk of cognitive impairment compared with persons without diabetes [17]. Another study in middle-aged and young older adults with T2DM suggested that HbA1c over 7 years of follow-up was not associated with cognitive function [4]. These contradictions between studies suggest that other factors may also influence whether glycemic control is associated with cognitive impairment.

If $\mathrm{HbA1c}$ is an important indicator of cognitive decline, this suggests that improving glycemic control in elderly patients is vital to decrease the risk of cognitive decline. However, understanding other factors that are also involved would help target the patients most at risk of cognitive decline. Therefore, the aim of this study was to investigate the association of $\mathrm{HbAlc}$ levels with MMSE decline in elderly patients with T2DM and find the correlative factors involved.

\section{Methods}

\section{Study design and patients}

This was a retrospective analysis of a community-based cohort study (BLSA II) [18], which included the patients with T2DM from 3 urban districts (Xicheng, Dongcheng, and Xuanwu) and 1 outer suburban area (Shunyi) of Beijing. The baseline data were collected from August 2010 to January 2011, and the last follow-up was undertaken in April 2014. The inclusion criteria were as follows: 1 ) aged $>55$ years; 2 ) diagnosed with T2DM that was under diet control or medication [9]. The exclusion criteria were: 1) acute critical illness or severe psychiatric diseases that would affect the scale evaluation such as dementia and depression; 2) blind, deaf, dumb, and vegetative; 3 ) complicated with severe diseases including heart, liver, renal diseases and malignant tumors. The patients were assigned into three groups according to their baseline HbA1c levels: HbA1c $<7,7 \% \leq$ HbA1c $<$ $8 \%$ and $\mathrm{HbA} 1 \mathrm{c} \geq 8 \%$.

The study was approved by the research ethics committee of Xuanwu Hospital of Capital Medical University before study initiation. Written informed consent was obtained from all participants for the original data collection.

\section{Clinical data collection and examination method}

The baseline information of the subjects was collected, including sex, age, smoking, alcohol consumption, education, whether they lived alone, income, physical exercise, dietary habits, intake of fruit and vegetables, body mass index (BMI), history of cerebrovascular disease (CED), history of cardiovascular disease (CVD) and peripheral vascular disease, history of hypertension, participation in community-based healthcare seminars and consultations, alanine aminotransferase (ALT), triglyceride (TG), total cholesterol (TC), high-density lipoprotein (HDL), low-density lipoprotein (LDL), glucose (GLU), urinary albumin (UA), creatinine $(\mathrm{Cr})$, apolipoprotein $\mathrm{E}$ (ApoE), and HbA1c. The biochemical analysis was performed by a Hitachi 7600 automatic biochemical analyzer (Hitachi high-tech, Fukuoka, Japan). The HbA1c level was determined by a Bio-Rad VARIANT ${ }^{\mathrm{m}}$ II TURBO Hemoglobin Testing System for HbA1c when baseline information was collected.

\section{Assessment of cognitive function}

The patient's cognitive function was evaluated by the Chinese edition of the Mini-Mental State Examination (MMSE) [19]. The MMSE was invented in 1975 and since then has been widely used as a scale for dementia. The total score was 30 and assessed by the raw MMSE values stratified threshold based on education years, which was validated by previous research. MMSE was examined at baseline as well as 3 years later during the follow-up.

\section{Definitions and follow up}

The change of MMSE was defined as the difference between baseline and follow-up values after 3 years.

The last follow up occurred between November 2013 and April 2014 in the form of a questionnaire in the community hospitals.

\section{Statistical analysis}

The data analysis was performed using $\mathrm{R}$ software (version 3.5.1; R Development Core Team 2018, www.R-project.org). The continuous variables that followed normal distribution were represented as the mean \pm standard deviation (SD). The continuous variables that did not 
Table 1 Baseline information of the patients with type 2 diabetes mellitus included in the study

\begin{tabular}{|c|c|c|c|c|c|}
\hline Characteristics & $\begin{array}{l}\text { Total }(n= \\
\text { 1519) }\end{array}$ & $\begin{array}{l}\text { Low group } \\
\text { HbA1c }<7 \%(n= \\
883)\end{array}$ & $\begin{array}{l}\text { Median group } \\
7 \% \leq \mathrm{HbA} 1 \mathrm{C}<8 \%(n= \\
333)\end{array}$ & $\begin{array}{l}\text { High group } \\
\text { HbA1c } \geq 8 \%(n= \\
303)\end{array}$ & $P$ \\
\hline Age (mean $\pm S D)$, years & $72 \pm 6.3$ & $71.8 \pm 6.3$ & $72.3 \pm 6.3$ & $72.1 \pm 6$ & 0.371 \\
\hline \multicolumn{6}{|l|}{ Age, years, n (\%) } \\
\hline $55-64$ & $249(16.4)$ & $155(17.6)$ & $52(15.6)$ & $42(13.9)$ & \multirow[t]{3}{*}{0.483} \\
\hline $65-74$ & $723(47.6)$ & $413(46.8)$ & $155(46.5)$ & $155(51.2)$ & \\
\hline$\geq 75$ & $547(36)$ & $315(35.7)$ & $126(37.8)$ & $106(35)$ & \\
\hline $\mathrm{Cr}$ & $70.2 \pm 26.2$ & $70.3 \pm 30.1$ & $70.9 \pm 19$ & $69.2 \pm 20.4$ & 0.701 \\
\hline GLU & $6.7 \pm 2.1$ & $5.8 \pm 0.9$ & $7 \pm 1.1$ & $9.2 \pm 3.2$ & $\begin{array}{l}< \\
0.001\end{array}$ \\
\hline $\mathrm{HbA1c}$ & $7 \pm 1.6$ & $6 \pm 0.6$ & $7.4 \pm 0.3$ & $9.5 \pm 1.6$ & $\begin{array}{l}< \\
0.001\end{array}$ \\
\hline $\mathrm{HDL}$ & $1.3 \pm 0.3$ & $1.3 \pm 0.3$ & $1.3 \pm 0.3$ & $1.3 \pm 0.3$ & 0.361 \\
\hline LDL & $2.9 \pm 0.7$ & $2.9 \pm 0.8$ & $2.9 \pm 0.7$ & $2.9 \pm 0.8$ & 0.971 \\
\hline TC & $5.2 \pm 1$ & $5.2 \pm 1.1$ & $5.2 \pm 1$ & $5.2 \pm 1$ & 0.965 \\
\hline TG & $1.7 \pm 1$ & $1.6 \pm 0.9$ & $1.7 \pm 0.8$ & $1.8 \pm 1.4$ & 0.01 \\
\hline UA & $327.1 \pm 89.7$ & $326.3 \pm 86.5$ & $339.3 \pm 95$ & $316.1 \pm 91.5$ & 0.005 \\
\hline ApoE23 & $1078(90.4)$ & $621(91.2)$ & $241(90.9)$ & $216(87.4)$ & 0.218 \\
\hline ApoE4 & $115(9.6)$ & $60(8.8)$ & $24(9.1)$ & $31(12.6)$ & \\
\hline \multicolumn{6}{|l|}{ Sex } \\
\hline male & $580(38.2)$ & $345(39.1)$ & $126(37.8)$ & $109(36)$ & \multirow[t]{2}{*}{0.625} \\
\hline female & $939(61.8)$ & $538(60.9)$ & $207(62.2)$ & $194(64)$ & \\
\hline \multicolumn{6}{|l|}{ Education } \\
\hline Elementary school and below & $534(36.1)$ & $280(32.6)$ & $137(42.2)$ & $117(39.9)$ & \multirow[t]{2}{*}{0.003} \\
\hline High school and above & $944(63.9)$ & $580(67.4)$ & $188(57.8)$ & $176(60.1)$ & \\
\hline \multicolumn{6}{|l|}{ Live Alone } \\
\hline yes & $104(6.9)$ & $64(7.3)$ & $23(6.9)$ & $17(5.6)$ & \multirow[t]{2}{*}{0.619} \\
\hline no & $1413(93.1)$ & $818(92.7)$ & $309(93.1)$ & $286(94.4)$ & \\
\hline \multicolumn{6}{|l|}{ income } \\
\hline $\begin{array}{l}\text { The monthly per capita income in the family } \\
\leq 3000\end{array}$ & $1098(79.6)$ & $643(80.8)$ & $235(77.3)$ & $220(78.9)$ & \multirow[t]{2}{*}{0.413} \\
\hline $\begin{array}{l}\text { The monthly per capita income in the family > } \\
3000\end{array}$ & $281(20.4)$ & $153(19.2)$ & $69(22.7)$ & $59(21.1)$ & \\
\hline \multicolumn{6}{|c|}{ Participation in healthcare seminar/consulting at least once a month } \\
\hline yes & $902(61.2)$ & $534(62.4)$ & $195(59.8)$ & $173(59.2)$ & \multirow[t]{2}{*}{0.539} \\
\hline no & $572(38.8)$ & $322(37.6)$ & $131(40.2)$ & $119(40.8)$ & \\
\hline \multicolumn{6}{|l|}{ smoke } \\
\hline no & $1361(89.6)$ & $795(90)$ & $303(91)$ & $263(86.8)$ & \multirow[t]{2}{*}{0.181} \\
\hline yes & $158(10.4)$ & $88(10)$ & $30(9)$ & $40(13.2)$ & \\
\hline \multicolumn{6}{|l|}{ drink } \\
\hline no & $1334(87.8)$ & $774(87.7)$ & $287(86.2)$ & $273(90.1)$ & \multirow[t]{2}{*}{0.313} \\
\hline yes & $185(12.2)$ & $109(12.3)$ & $46(13.8)$ & $30(9.9)$ & \\
\hline \multicolumn{6}{|l|}{ Physical Activity } \\
\hline Exercise less than $30 \mathrm{~min} /$ day & $363(24.6)$ & $218(25.3)$ & $78(24)$ & $67(22.9)$ & \multirow[t]{2}{*}{0.671} \\
\hline Exercise more than $30 \mathrm{~min} /$ day & $1115(75.4)$ & $642(74.7)$ & $247(76)$ & $226(77.1)$ & \\
\hline
\end{tabular}

\footnotetext{
High-protein diet
} 
Table 1 Baseline information of the patients with type 2 diabetes mellitus included in the study (Continued)

\begin{tabular}{|c|c|c|c|c|c|}
\hline Characteristics & $\begin{array}{l}\text { Total }(n= \\
1519)\end{array}$ & $\begin{array}{l}\text { Low group } \\
\text { HbA1C }<7 \%(n= \\
883)\end{array}$ & $\begin{array}{l}\text { Median group } \\
7 \% \leq \mathrm{HbA} 1 \mathrm{C}<8 \%(n= \\
333)\end{array}$ & $\begin{array}{l}\text { High group } \\
\text { HbA1c } \geq 8 \%(n= \\
303)\end{array}$ & $P$ \\
\hline High-protein diet $<=1$ item & $276(18.2)$ & $160(18.1)$ & $50(15)$ & $66(21.8)$ & 0.087 \\
\hline High-protein diet: 2-3 items & $1243(81.8)$ & $723(81.9)$ & $283(85)$ & $237(78.2)$ & \\
\hline \multicolumn{6}{|c|}{ Intake of fruits/vegetables more than twice a day } \\
\hline no & $165(10.9)$ & $90(10.2)$ & $33(9.9)$ & $42(13.9)$ & 0.171 \\
\hline yes & $1354(89.1)$ & $793(89.8)$ & $300(90.1)$ & $261(86.1)$ & \\
\hline \multicolumn{6}{|l|}{ BMI } \\
\hline normal & $534(35.2)$ & $346(39.2)$ & $98(29.4)$ & $90(29.7)$ & 0.001 \\
\hline Overweight or obesity & $984(64.8)$ & $536(60.8)$ & $235(70.6)$ & $213(70.3)$ & \\
\hline \multicolumn{6}{|l|}{ CVD History } \\
\hline no & $748(49.2)$ & $417(47.2)$ & $166(49.8)$ & $165(54.5)$ & 0.092 \\
\hline yes & $771(50.8)$ & $466(52.8)$ & $167(50.2)$ & $138(45.5)$ & \\
\hline \multicolumn{6}{|l|}{ CED History } \\
\hline no & $1131(74.5)$ & $646(73.2)$ & $244(73.3)$ & $241(79.5)$ & 0.077 \\
\hline yes & $388(25.5)$ & $237(26.8)$ & $89(26.7)$ & $62(20.5)$ & \\
\hline \multicolumn{6}{|l|}{ HP History } \\
\hline no & $128(8.4)$ & $85(9.6)$ & $26(7.8)$ & $17(5.6)$ & 0.085 \\
\hline yes & 1391 (91.6) & $798(90.4)$ & $307(92.2)$ & $286(94.4)$ & \\
\hline MMSE score (baseline) & $28.5 \pm 2.2$ & $28.5 \pm 2.2$ & $28.4 \pm 2.2$ & $28.6 \pm 2.4$ & 0.51 \\
\hline MMSE score (follow-up) & $27.3 \pm 3.6$ & $27.4 \pm 3.3$ & $27.3 \pm 3.9$ & $26.9 \pm 3.8$ & 0.086 \\
\hline MMSE variation & $-1.2 \pm 3.5$ & $-1.1 \pm 3.3$ & $-1.1 \pm 3.6$ & $-1.7 \pm 3.6$ & 0.022 \\
\hline
\end{tabular}

Abbreviations: triglyceride (TG), total cholesterol (TC), high-density lipoprotein (HDL), low-density lipoprotein (LDL), glucose (GLU), urinary albumin (UA), creatinine $(\mathrm{Cr})$, apolipoprotein E (ApoE), glycated hemoglobin (HbA1c), body mass index (BMI), cardiovascular disease (CVD), cerebrovascular disease (CED), hypertension (HP), mini-mental state examination (MMSE)

follow normal distribution were represented by median (range or interquartile range (IQR)). The categorical variables were represented as $\mathrm{n}(\%)$. The continuous variables that follow normal distribution were examined by $\mathrm{t}$-test or analysis of variance (ANOVA). The continuous variables that did not follow normal distribution were tested by the Mann-Whitney U or Kruskal-Wallis test. The categorical variables were tested by the $\chi^{2}$ test or Fisher exact test. The association analysis was performed by univariate or multivariate regression. A $P<0.05$ value was considered statistically significant.

\section{Results}

\section{Baseline characteristics}

The study included 1519 subjects. Their mean age was $72 \pm 6.3$ years old. Among them, 580 (38.2\%) were male, and $939(61.8 \%)$ were female. The numbers of subjects in the three groups were 883 in the Low group, 333 in the Median group, and 303 in the High group. The baseline information collected from the patients is shown in Table 1. Age, gender, and most of the clinical indexes were similar between the groups except GLU $(P<0.001)$, HbA1c $(\mathrm{P}<0.001)$, TGP $=0.01)$, and UA $(P=0.005)$. The number of patients educated below elementary school level $(P=0.003)$, BMI $(P=0.001)$, and MMSE variation $(P=0.022)$ but not the MMSE scores at baseline or follow-up were also different between the groups.

\section{Linear regression analysis of factors related to the severity of the decline in MMSE score}

Univariate analysis of factors related to a decline in MMSE score (Table 2), identified age $\geq 75$ years $($ Beta $=$ $0.9795 \%$ confidence interval $(\mathrm{CI}): 0.42-1.51, P=0.001)$, education below elementary school level $($ Beta $=1.17$ 95\%CI:0.75-1.59, $P<0.001$ ), not participating in seminars or consultation on healthcare (Beta $=0.4395 \% \mathrm{CI}$ : 0.08-0.78, $P=0.017$ ), physical activity more than 30 $\mathrm{min} /$ day (Beta $=-0.4$ 95\%CI:-0.8-0, $P=0.05$ ), CED history (Beta $=0.49$ 95\%CI:0.1-0.89, $P=0.015$ ), MMSE score at baseline (Beta $=0.56$ 95\%CI:0.47-0.64, $P<$ 0.001 ), and HBA1c $\geq 8 \%$ (Beta $=0.6195 \%$ CI:0.08-1.14, $P=0.024)$.

Factors that had a level at or close to significance $(P<$ 0.1 ) were then included in multivariate analysis for independent factors related to MMSE decline (Table 3). This showed that age $\geq 75$ years (Beta $=0.99$ 95\%CI:0.45-1.52, $P<0.001)$, education to elementary school and below 
Table 2 Univariate regression analysis for factors related to MMSE decline in elderly patients with type 2 diabetes mellitus

\begin{tabular}{|c|c|c|}
\hline Characteristics & Beta $(95 \% \mathrm{Cl})$ & $P$-value \\
\hline Female & $0.15(-0.29-0.59)$ & 0.505 \\
\hline \multicolumn{3}{|l|}{ Age, years } \\
\hline $55-64$ & 1 & \\
\hline $65-74$ & $-0.06(-0.56-0.43)$ & 0.798 \\
\hline$\geq 75$ & $0.97(0.42-1.51)$ & 0.001 \\
\hline Elementary school and below & $1.17(0.75-1.59)$ & $<0.001$ \\
\hline Lives alone, no & $0.44(-0.25-1.13)$ & 0.208 \\
\hline Participation in healthcare seminars/consultation at least once a month, no & $0.43(0.08-0.78)$ & 0.017 \\
\hline Smoker & $0.03(-0.59-0.65)$ & 0.919 \\
\hline Drinking alcohol & $-0.18(-0.76-0.41)$ & 0.55 \\
\hline Physical Activity of more than $30 \mathrm{~min} /$ day & $-0.4(-0.8-0)$ & 0.05 \\
\hline High-protein diet: $2-3$ items & $0.3(-0.15-0.75)$ & 0.197 \\
\hline Intake of fruits/vegetables more than twice a day, yes & $0.08(-0.48-0.64)$ & 0.773 \\
\hline Overweight or obese & $-0.11(-0.48-0.26)$ & 0.555 \\
\hline CVD History, yes & $0.05(-0.3-0.39)$ & 0.793 \\
\hline CED History, yes & $0.49(0.1-0.89)$ & 0.015 \\
\hline HP History, yes & $-0.23(-0.86-0.4)$ & 0.476 \\
\hline MMSE score (baseline) & $0.56(0.47-0.64)$ & $<0.001$ \\
\hline TG & $-0.04(-0.26-0.17)$ & 0.7 \\
\hline TC & $0.08(-0.41-0.57)$ & 0.75 \\
\hline $\mathrm{HDL}$ & $-0.21(-0.92-0.51)$ & 0.571 \\
\hline LDL & $-0.19(-0.81-0.44)$ & 0.56 \\
\hline UA & $0(0-0)$ & 0.972 \\
\hline $\mathrm{Cr}$ & $0.01(0-0.01)$ & 0.099 \\
\hline \multicolumn{3}{|l|}{$\mathrm{HbA1c}$} \\
\hline $7 \% \leq \mathrm{HbA} 1 \mathrm{c}<8 \%$ & 1 & \\
\hline $\mathrm{HbA} 1 \mathrm{c}<7 \%$ & $0.05(-0.37-0.48)$ & 0.808 \\
\hline $\mathrm{HbA} 1 \mathrm{c} \geq 8 \%$ & $0.61(0.08-1.14)$ & 0.024 \\
\hline
\end{tabular}

Abbreviations: $\mathrm{Cl}$ confidence interval, $T G$ triglyceride, $T C$ total cholesterol, $H D L$ high-density lipoprotein, $L D L$ low-density lipoprotein, $U A$ urinary albumin, $C r$ creatinine, HbA1c glycated hemoglobin, CVD cardiovascular disease, CED cerebrovascular disease, HP hypertension, MMSE mini-mental state examination

(Beta $=1.18$ 95\%CI:0.78-1.58, $P<0.001$, not participating in healthcare seminars or consultation at least once a month (Beta $=0.42$ 95\%CI:0.07-0.77, $P=0.018$ ), physical activity for more than $30 \mathrm{~min} /$ day (Beta $=-0.4495 \% \mathrm{CI}$ :0.83--0.05, $P=0.029$ ), a CED history (Beta $=0.48$ 95\%CI: $0.09-0.87, P=0.015)$, MMSE score at baseline (Beta $=$ 0.57 95\%CI:0.49-0.65, $P<0.001)$, and HbA1c $\geq 8 \%$ (Beta $=0.58$ 95\%CI:0.06-1.11, $\mathrm{P}=0.029)$ all remained significant factors.

\section{Logistic regression analysis of factors related to the decline in MMSE score}

When logistic regression was used for analysis of factors related to a decline in MMSE score (Table 4), the univariate analysis identified age $\geq 75$ years (odds ratio $(\mathrm{OR})=1.66 \quad 95 \% \quad \mathrm{CI}: 1.26-2.19, \quad P<0.001), \quad$ physical activity than $30 \mathrm{~min} /$ day $(\mathrm{OR}=0.77 \quad 95 \% \mathrm{CI}: 0.62-0.92$, $P=0.022)$, MMSE score at baseline $(\mathrm{OR}=1.4195 \% \mathrm{CI}$ : 1.35-1.49, $P<0.001)$, LDL (OR $=0.85$ 95\%CI:0.75-0.96, $P=0.01)$ and HBA1c $\geq 8 \%(\mathrm{OR}=1.5295 \% \mathrm{CI}: 1.13-2.03$, $P=0.005)$.

The multivariate analysis is shown in Table 5. This showed that age $\geq 75$ years $(\mathrm{OR}=1.97$ 95\%CI:1.432.72, $P<0.001)$, education to elementary school and below $(\mathrm{OR}=1.91$ 95\%CI:1.48-2.45, $\mathrm{P}<0.001$, physical activity less than $30 \mathrm{~min} /$ day $(\mathrm{OR}=0.79$ 95\%CI:0.62-1, $P=0.048)$, a CED history $(\mathrm{OR}=1.395 \% \mathrm{CI}: 1.03-1.64$, $P=0.029)$, MMSE score at baseline $(\mathrm{OR}=1.5695 \% \mathrm{CI}$ : $1.47-1.66, \quad \mathrm{P}<0.001)$, and $\mathrm{HbA} 1 \mathrm{c} \geq 8 \% \quad(\mathrm{OR}=1.52$ 95\%CI:1.13-2.12, $P=0.007)$ were all significant factors independently associated with decline in MMSE score. 
Table 3 Multivariate analysis of factors independently associated with MMSE decline value in elderly patients with type 2 diabetes mellitus

\begin{tabular}{lll}
\hline Characteristics & Beta 95\%Cl & P-value \\
\hline Age, years & & \\
$55-64$ & $-0.05(-0.54-0.44)$ & 0.841 \\
$65-74$ & $0.99(0.45-1.52)$ & $<0.001$ \\
$\geq 75$ & $1.18(0.78-1.58)$ & $<0.001$ \\
Elementary school and below & $0.42(0.07-0.77)$ & 0.018 \\
Participation in healthcare seminar/consulting at least once a month, no & $-0.44(-0.83-0.05)$ & 0.029 \\
Physical activity for more than 30 min/day & $0.48(0.09-0.87)$ & 0.015 \\
CED History, yes & $0.57(0.49-0.65)$ & $<0.001$ \\
MMSE score (baseline) & & 0.807 \\
HbA1c & 1 & 0.029 \\
$7 \% \leq$ HbA1c < 8\% & & $0.05(-0.37-0.47)$ \\
HbA1c < 7\% & $0.58(0.06-1.11)$ & \\
HbA1c $\geq 8 \%$ & &
\end{tabular}

Abbreviations: CED cerebrovascular disease, MMSE mini-mental state examination, HbA1c glycated hemoglobin

Association between MMSE decline and HbA1c level

Figure 1 shows the association between MMSE decline and HbA1c level. It can be seen that patients with HbA1c levels $\geq 8 \%$ (the High group) showed more decline than those in the other two groups, and the risk of MMSE decline increased above $8 \%$.

\section{Discussion}

The aim of this study was to investigate the association between HbA1c levels and MMSE decline in elderly patients with T2DM. The results show that age $\geq 75$ years, education below elementary school level, not participating in seminars or consultation on healthcare, physical activity less than $30 \mathrm{~min} /$ day, cerebrovascular disease history, MMSE score at baseline, and HBA1c $\geq 8 \%$ were all associated with MMSE decline by univariate and multivariate analysis. After adjustment for the other factors, $\mathrm{HbA} 1 \mathrm{c} \geq 8 \%$ was independently associated with MMSE decline and its severity.

There has been some controversy over whether HbA1c levels as an indicator of glycemic control in patients with T2DM can be used to predict cognitive decline. There is strong evidence that HbA1c is associated with cognitive decline [10]. Most studies suggest higher levels of HbA1c correlate with worse cognitive function in individuals with T2DM [12, 13], but some do not show this correlation [11]. Studies using high HbA1c levels to measure cognitive decline have also shown conflicting results [4, 14-17]. This conflict is likely to arise from other contributing factors. The results of this study showed that a number of factors were related to cognitive decline in elderly patients with T2DM including age $\geq 75$ years, education below elementary school level, not participating in seminars or consultation on healthcare, undertaking physical activity for less than 30 min/day, cerebrovascular disease history, and MMSE score at baseline as well as $\mathrm{HbA} 1 \mathrm{c} \geq 8 \%$. However, when the model was adjusted for these factors, this study found that $\mathrm{HbA} 1 \mathrm{c} \geq 8 \%$ was independently associated with cognitive decline. This result suggests that active measures should be taken to ensure that elderly patients make every effort to control their glucose levels below $8 \%$ to prevent cognitive decline $[20,21]$. There are several potential mechanisms for higher glucose levels, increasing the risk of cognitive decline. These include acute hyperglycemia, where very high blood glucose concentrations may cause alterations in cerebral blood flow or osmotic changes in neurons; chronic hyperglycemia, which may cause structural changes in the brain through mechanisms such as cerebral microvascular disease [22, 23]; and insulin resistance, where the failure of brain cells to respond to insulin might result in synaptic, metabolic and immune response impairments. However, while the results of this study concentrated on HbA1c levels, which indicate glucose levels over the previous 3 months, there is evidence indicating that fluctuations or peaks in glucose levels may also be linked to cognitive decline and dementia risk [20, 21]. Glycemic fluctuations may have a greater adverse effect on endothelial function and induce more oxidative stress than sustained hyperglycemia, potentially leading to greater cognitive decline [24]. So, the relationship between glucose control and cognitive decline is likely to be complex, and efforts to prevent glucose fluctuations might also be important. Further study is needed to fully understand the mechanisms involved.

Age is clearly related to the degree of decline in MMSE scores both in populations with and without 
Table 4 Univariate logistic regression analysis of MMSE decline

\begin{tabular}{|c|c|c|}
\hline Characteristics & OR_95CI & P_value \\
\hline Female & $0.94(0.77-1.14)$ & 0.508 \\
\hline \multicolumn{3}{|l|}{ Age, years } \\
\hline $55-64$ & 1 & \\
\hline $65-74$ & $1.13(0.87-1.48)$ & 0.363 \\
\hline$\geq 75$ & $1.66(1.26-2.19)$ & $<0.001$ \\
\hline Elementary school and below & $0.83(0.68-1.01)$ & 0.069 \\
\hline Lives alone, no & $1.3(0.9-1.88)$ & 0.162 \\
\hline $\begin{array}{l}\text { Participation in healthcare } \\
\text { seminars/consultation } \\
\text { at least once a month, no }\end{array}$ & $1.09(0.89-1.32)$ & 0.402 \\
\hline Smoker & $1.07(0.79-1.46)$ & 0.648 \\
\hline Drinking alcohol & $0.97(0.73-1.29)$ & 0.837 \\
\hline $\begin{array}{l}\text { Physical Activity of } \\
\text { more than } 30 \mathrm{~min} / \text { day }\end{array}$ & $0.77(0.62-0.96)$ & 0.022 \\
\hline High-protein diet: 2-3 items & $1.25(0.98-1.6)$ & 0.066 \\
\hline $\begin{array}{l}\text { Intake of fruits/vegetables } \\
\text { more than twice a day, yes }\end{array}$ & $0.75(0.55-1.01)$ & 0.061 \\
\hline Overweight or obese & $0.93(0.76-1.13)$ & 0.443 \\
\hline CVD History, yes & $1.06(0.88-1.27)$ & 0.57 \\
\hline CED History, yes & $1.16(0.94-1.44)$ & 0.177 \\
\hline HP History, yes & $1.16(0.83-1.63)$ & 0.373 \\
\hline MMSE score (baseline) & $1.41(1.35-1.49)$ & $<0.001$ \\
\hline TG & $0.99(0.9-1.08)$ & 0.773 \\
\hline TC & $0.92(0.84-1.01)$ & 0.067 \\
\hline $\mathrm{HDL}$ & $0.82(0.61-1.12)$ & 0.21 \\
\hline LDL & $0.85(0.75-0.96)$ & 0.01 \\
\hline UA & $1(1-1)$ & 0.629 \\
\hline $\mathrm{Cr}$ & $1(1-1.01)$ & 0.063 \\
\hline \multicolumn{3}{|l|}{$\mathrm{HbA1c}$} \\
\hline $7 \% \leq \mathrm{HbA} 1 \mathrm{c}<8 \%$ & 1 & \\
\hline $\mathrm{HbA} 1 \mathrm{c}<>7 \%$ & $1.13(0.89-1.42)$ & 0.314 \\
\hline $\mathrm{HbA} 1 \mathrm{c} \geq 8 \%$ & $1.52(1.13-2.03)$ & 0.005 \\
\hline
\end{tabular}

T2DM $[25,26]$. So, the result that age $\geq 75$ years was related to a decline in MMSE was consistent with previous studies. Other factors related to MMSE decline in this study may also influence the glycemic control of the patients. For example, education below elementary school level and monthly participation in seminars or consultation on healthcare are both likely to influence whether the patient adheres to their medication or diet to achieve glycemic control. This is supported by another study that found that higher education level was a protective factor for cognitive impairment in elderly patients with T2DM [27]. Physical activity has also been shown by other studies to be an important protective factor against cognitive decline, as summarized in a
Table 5 Multivariate logistic regression analysis of MMSE decline

\begin{tabular}{|c|c|c|}
\hline Characteristics & OR_95Cl & P-value \\
\hline Female & $1.19(0.92-1.55)$ & 0.185 \\
\hline \multicolumn{3}{|l|}{ Age, years } \\
\hline $55-64$ & 1 & \\
\hline $65-74$ & $1.12(0.84-1.49)$ & 0.456 \\
\hline$\geq 75$ & $1.97(1.43-2.72)$ & $<0.001$ \\
\hline Elementary school and below & $1.91(1.48-2.45)$ & $<0.001$ \\
\hline Lives Alone, no & $1.36(0.9-2.06)$ & 0.144 \\
\hline $\begin{array}{l}\text { Participation in healthcare } \\
\text { seminar/consulting at } \\
\text { least once a month, no }\end{array}$ & $1.28(1.04-1.58)$ & 0.022 \\
\hline smoke & $1.11(0.77-1.6)$ & 0.588 \\
\hline drink & $0.86(0.61-1.21)$ & 0.383 \\
\hline PhyAct more than $30 \mathrm{~min} /$ day & $0.79(0.62-1)$ & 0.048 \\
\hline High-protein diet: 2-3 items & $1.14(0.87-1.49)$ & 0.344 \\
\hline $\begin{array}{l}\text { Intake of fruits/vegetables } \\
\text { more than twice a day, yes }\end{array}$ & $0.84(0.6-1.17)$ & 0.302 \\
\hline Overweight or obesity & $0.99(0.8-1.23)$ & 0.937 \\
\hline CVD His, yes & $1.06(0.86-1.3)$ & 0.601 \\
\hline CED His, yes & $1.3(1.03-1.64)$ & 0.029 \\
\hline HP His, yes & $0.92(0.63-1.34)$ & 0.67 \\
\hline MMSE score (baseline) & $1.56(1.47-1.66)$ & $<0.001$ \\
\hline TG & $0.97(0.85-1.1)$ & 0.644 \\
\hline TC & $1.09(0.81-1.46)$ & 0.585 \\
\hline $\mathrm{HDL}$ & $0.9(0.59-1.39)$ & 0.644 \\
\hline LDL & $0.84(0.58-1.23)$ & 0.373 \\
\hline UA & $1(1-1)$ & 0.51 \\
\hline $\mathrm{Cr}$ & $1(1-1.01)$ & 0.49 \\
\hline \multicolumn{3}{|l|}{$\mathrm{HbA1c}$} \\
\hline $7 \% \leq \mathrm{HbA} 1 \mathrm{c}<8 \%$ & 1 & \\
\hline $\mathrm{HbA} 1 \mathrm{c}<7 \%$ & $1.18(0.91-1.51)$ & 0.205 \\
\hline $\mathrm{HbA} 1 \mathrm{c} \geq 8 \%$ & $1.55(1.13-2.12)$ & 0.007 \\
\hline
\end{tabular}

Note analysis was by stepwise regression

Abbreviations: $\mathrm{Cl}$ confidence interval, TG triglyceride, TC total cholesterol, HDL high-density lipoprotein, $L D L$ low-density lipoprotein, $U A$ urinary albumin, $C r$ creatinine, $H b A 1 c$ glycated hemoglobin, CVD cardiovascular disease, CED cerebrovascular disease, HP hypertension, MMSE mini-mental state examination

systematic review [28]. Cardiovascular disease history was also identified as an important factor in this study. This is supported by the established view that cardiovascular risk factors are related to late-life cognitive decline [29]. Both physical activity and cardiovascular risk factors are considered so important that the World Dementia Council (WDC) concluded that regular physical activity and management of cardiovascular risk factors, including diabetes, obesity, smoking, and hypertension, would reduce the risk of cognitive decline [30].

This study has some limitations. The baseline measurement of $\mathrm{HbAlc}$ was undertaken at one time point 


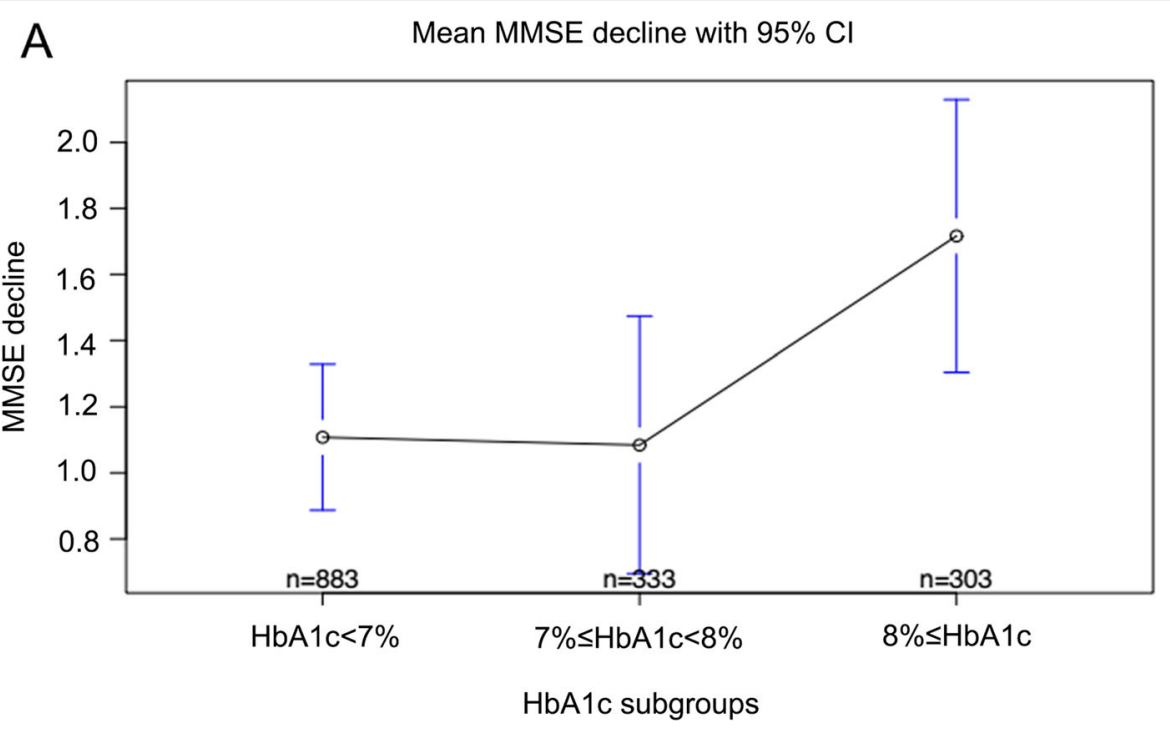

B Dose-response relationship between $\mathrm{HbA} 1 \mathrm{c}$ and relative risk of MMSE decline

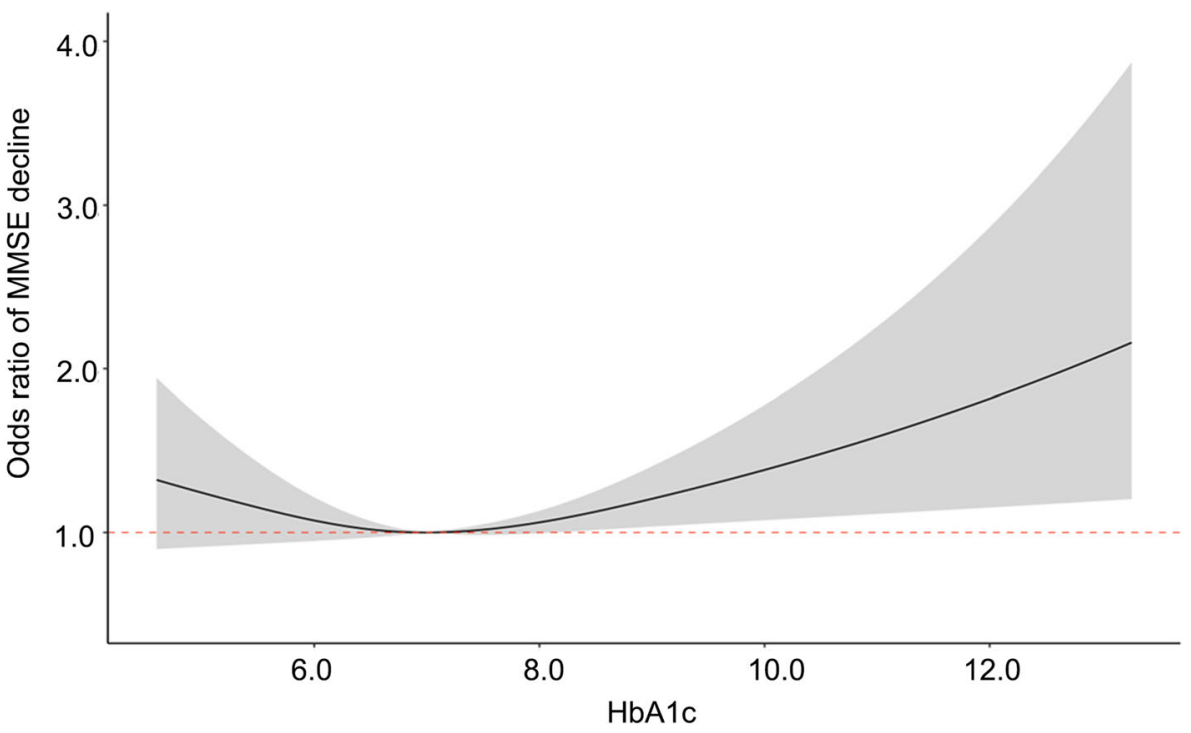

Fig. 1 Graphs showing the association of cognitive decline with glycated hemoglobin (HbA1c) levels. a: Mini mental state examination (MMSE) decline in the three groups based on HbA1c levels. b: Dose response relationship between $\mathrm{HbA1c}$ and risk of MMSE decline

and may not have been a true reflection of the typical value. As a retrospective study, no cause and effect can be deduced from the results. Cognitive function was based on MMSE alone, and other measures of cognitive function may not support the results. We did not have the full data regarding the medication use for all patients, some drugs such as benzodiazepines are known to impair cognitive function, so there may have been some differences in their use between groups that may have influenced the results of the study. The 3-year follow-up might be too short to study a decrease in cognitive functions. But the follow up has continued, and long-term changes of cognitive functions will be analyzed in the future.

\section{Conclusions}

In elderly patients with type 2 diabetes, a number of factors were related to MMSE decline. Nevertheless, the analysis suggested that $\mathrm{HbA} 1 \mathrm{c} \geq 8 \%$ was an independent factor for cognitive decline and was also associated with the severity of the cognitive decline.

\section{Abbreviations}

HbA1c: Glycated hemoglobin; MMSE: Mini-Mental State Examination; T2DM: Type 2 diabetes mellitus; BMI: Body mass index; CED: Cerebrovascular disease; CVD: Cardiovascular disease; ALT: Alanine aminotransferase; TG: Triglyceride; TC: Total cholesterol; HDL: High-density lipoprotein; LDL: Low-density lipoprotein; GLU: Glucose; UA: Urinary albumin; Cr: Creatinine; SD: Standard deviation; IQR: Interquartile range; ANOVA: Analysis of variance 


\section{Acknowledgments}

Not applicable.

\section{Authors' contributions}

Conceptualization, CP; methodology, ZL, ZZ, XSL; software, HC, ZZ; validation CP; formal analysis, ZL, HC, ZZ; investigation, ZL, HC, ZZ, XSL; resources, CP; data curation, HC, ZZ; writing —original draft preparation, ZL; writing-review and editing, ZL; visualization, ZL; supervision, $C P$; project administration, $C P$; funding acquisition, CP. All authors have read and agreed to the published version of the manuscript.

\section{Funding}

This research was funded by the National Key Research and Development Program of China (grant number 1312000). The funders had no role in the design of the study; in the collection, analyses, or interpretation of data; in the writing of the manuscript, or in the decision to publish the results. Recommended unit: Beijing Municipal Science \& Technology Commission. Project name: Construction and Application of Big Data and Biological Sample Bank Platform for Clinical Research of Neurodegenerative Diseases. Item: Prevention and control of major chronic non-communicable diseases.

\section{Availability of data and materials}

Data sharing is not applicable to this article, as no datasets were generated or analyzed during the current study.

\section{Ethics approval and consent to participate}

The study was approved by the research ethics committee of Xuanwu Hospital of Capital Medical University before study initiation. Written informed consent was obtained from all participants for the original data collection

\section{Consent for publication}

Not applicable.

\section{Competing interests}

The authors declare that they have no competing interests.

\section{Author details}

'Department of Endocrinology, Beijing Institute of Geriatrics, Xuanwu Hospital of Capital Medical University, Beijing, China. ${ }^{2}$ National Clinical Research Center for Geriatric Disorders, Xuanwu Hospital of Capital Medical University, 45 Changchun Road, Xicheng District, Beijing, China. ${ }^{3}$ Department of Neurobiology, Geriatrics, and Neurology, Xuanwu Hospital, No. 45 Changchun St., Xicheng District, Beijing, China. ${ }^{4}$ Department of Neurology, Beijing Institute of Geriatrics, Xuanwu Hospital of Capital Medical University, Beijing 100053, China. ${ }^{5}$ Parkinson's Disease Center of Beijing Institute for Brain Disorders, Beijing 100053, China. ${ }^{6}$ Key Laboratory on Neurodegenerative Disease of Ministry of Education, Beijing 100053, China. ${ }^{7}$ Beijing Key Laboratory for Parkinson's Disease, Beijing 100053, China. ${ }^{8}$ National Clinical Research Center for Geriatric Disorders, Beijing 100053, China.

Received: 26 February 2020 Accepted: 11 August 2020 Published online: 25 August 2020

\section{References}

1. Chen L, Magliano DJ, Zimmet PZ. The worldwide epidemiology of type 2 diabetes mellitus--present and future perspectives. Nat Rev Endocrinol. 2011;8:228-36

2. Zheng Y, Ley SH, Hu FB. Global aetiology and epidemiology of type 2 diabetes mellitus and its complications. Nat Rev Endocrinol. 2018;14:88-98.

3. Kautzky-Willer A, Harreiter J, Pacini G. Sex and gender differences in risk, pathophysiology and complications of type 2 diabetes mellitus. Endocr Rev. 2016;37:278-316.

4. Beavers KM, Leng I, Rapp SR, Miller ME, Houston DK, Marsh AP, et al. Effects of longitudinal glucose exposure on cognitive and physical function: results from the action for health in diabetes movement and memory study. J Am Geriatr Soc. 2017:65:137-45.

5. Dybjer E, Nilsson PM, Engstrom G, Helmer C, Nagga K. Pre-diabetes and diabetes are independently associated with adverse cognitive test results: a cross-sectional, population-based study. BMC Endocr Disord. 2018;18:91.
6. Reijmer YD, van den Berg E, Ruis C, Kappelle LJ, Biessels GJ. Cognitive dysfunction in patients with type 2 diabetes. Diabetes Metab Res Rev. 2010; 26:507-19.

7. Rawlings AM, Sharrett AR, Schneider AL, Coresh J, Albert M, Couper D, et al. Diabetes in midlife and cognitive change over 20 years: a cohort study. Ann Intern Med. 2014;161:785-93.

8. Cheng G, Huang C, Deng H, Wang H. Diabetes as a risk factor for dementia and mild cognitive impairment: a meta-analysis of longitudinal studies. Intern Med J. 2012;42:484-91.

9. Davies MJ, D'Alessio DA, Fradkin J, Kernan WN, Mathieu C, Mingrone G, et al. Management of Hyperglycemia in type 2 diabetes, 2018. A consensus report by the American Diabetes Association (ADA) and the European Association for the Study of diabetes (EASD). Diabetes Care. 2018;41:2669701.

10. Zheng F, Yan L, Yang Z, Zhong B, Xie W. HbA1C, diabetes and cognitive decline: the English longitudinal study of ageing. Diabetologia. 2018;61:83948.

11. Saczynski JS, Jonsdottir MK, Garcia ME, Jonsson PV, Peila R, Eiriksdottir G, et al. Cognitive impairment: an increasingly important complication of type 2 diabetes: the age, gene/environment susceptibility--Reykjavik study. Am J Epidemiol. 2008;168:1132-9.

12. Nguyen HT, Grzywacz JG, Arcury TA, Chapman C, Kirk JK, Ip EH, et al. Linking glycemic control and executive function in rural older adults with diabetes mellitus. J Am Geriatr Soc. 2010;58:1123-7.

13. Cukierman-Yaffe T, Gerstein HC, Williamson JD, Lazar RM, Lovato L, Miller $M E$, et al. Relationship between baseline glycemic control and cognitive function in individuals with type 2 diabetes and other cardiovascular risk factors: the action to control cardiovascular risk in diabetes-memory in diabetes (ACCORD-MIND) trial. Diabetes Care. 2009;32:221-6.

14. Yaffe K, Falvey C, Hamilton N, Schwartz AV, Simonsick EM, Satterfield S, et al. Diabetes, glucose control, and 9-year cognitive decline among older adults without dementia. Arch Neurol. 2012;69:1170-5.

15. Kanaya AM, Barrett-Connor E, Gildengorin G, Yaffe K. Change in cognitive function by glucose tolerance status in older adults: a 4-year prospective study of the rancho Bernardo study cohort. Arch Intern Med. 2004;164: 1327-33.

16. Christman AL, Matsushita K, Gottesman RF, Mosley T, Alonso A, Coresh J, et al. Glycated haemoglobin and cognitive decline: the atherosclerosis risk in communities (ARIC) study. Diabetologia. 2011;54:1645-52.

17. Rawlings AM, Sharrett AR, Albert MS, Coresh J, Windham BG, Power MC et al. The Association of Late-Life Diabetes Status and Hyperglycemia with Incident Mild Cognitive Impairment and dementia: the ARIC study. Diabetes Care. 2019:42:1248-54

18. Lu X, Li X, Zhao Y, Zheng Z, Guan S, Chan P. Contemporary epidemiology of gout and hyperuricemia in community elderly in Beijing. Int J Rheum Dis. 2014;17:400-7

19. Li G, Shen Y, Chen C, Li S, Zhang W, Liu M. Mini Mental State Examination (MMSE) in different population test study. Chinese Mental Health J. 1989;4: 148-51.

20. Geijselaers SLC, Sep SJS, Stehouwer CDA, Biessels GJ. Glucose regulation, cognition, and brain MRI in type 2 diabetes: a systematic review. Lancet Diabetes Endocrinol. 2015;3:75-89.

21. Rawlings AM, Sharrett AR, Mosley TH, Ballew SH, Deal JA, Selvin E. Glucose peaks and the risk of dementia and 20-year cognitive decline. Diabetes Care. 2017:40:879-86.

22. Pandini G, Pace V, Copani A, Squatrito S, Milardi D, Vigneri R. Insulin has multiple antiamyloidogenic effects on human neuronal cells. Endocrinology. 2013;154:375-87.

23. Strachan MW. R D Lawrence lecture 2010. The brain as a target organ in type 2 diabetes: exploring the links with cognitive impairment and dementia. Diabet Med. 2011;28:141-7

24. Ceriello A, Esposito K, Piconi L, Ihnat MA, Thorpe JE, Testa R, et al. Oscillating glucose is more deleterious to endothelial function and oxidative stress than mean glucose in normal and type 2 diabetic patients. Diabetes. 2008; 57:1349-54

25. Li H, Jia J, Yang Z. Mini-mental state examination in elderly Chinese: a population-based normative study. J Alzheimers Dis. 2016;53:487-96.

26. Falk N, Cole A, Meredith TJ. Evaluation of suspected dementia. Am Fam Physician. 2018;97:398-405.

27. Ma L, Li Y. Cognitive function and insulin resistance in elderly patients with type 2 diabetes. Neurol Res. 2017;39:259-63. 
28. Podolski N, Brixius K, Predel HG, Brinkmann C. Effects of regular physical activity on the cognitive performance of type 2 diabetic patients: a systematic review. Metab Syndr Relat Disord. 2017;15:481-93..

29. Feinkohl I, Keller M, Robertson CM, Morling JR, McLachlan S, Frier BM, et al. Cardiovascular risk factors and cognitive decline in older people with type 2 diabetes. Diabetologia. 2015;58:1637-45.

30. Baumgart M, Snyder HM, Carrillo MC, Fazio S, Kim H, Johns H. Summary of the evidence on modifiable risk factors for cognitive decline and dementia: a population-based perspective. Alzheimers Dement. 2015;11:718-26.

\section{Publisher's Note}

Springer Nature remains neutral with regard to jurisdictional claims in published maps and institutional affiliations.

Ready to submit your research? Choose BMC and benefit from:

- fast, convenient online submission

- thorough peer review by experienced researchers in your field

- rapid publication on acceptance

- support for research data, including large and complex data types

- gold Open Access which fosters wider collaboration and increased citations

- maximum visibility for your research: over $100 \mathrm{M}$ website views per year

At BMC, research is always in progress.

Learn more biomedcentral.com/submissions 